\title{
Evaluasi Pembelajaran Daring Mahasiswa pada Mata Kuliah Pembelajaran Matematika di SD
}

\section{Refiona Andika1*, Sherlyane Hendri2}

1,2 Program Studi Pendidikan Guru Sekolah dasar, Universitas Negeri Padang, Padang, Indonesia

\section{ART ICLE INFO}

\section{Article history:}

Received September 02, 2021

Revised September 03, 2021

Accepted October 14, 2021

Available online October 25, 2021

Kata Kunci:

Pembelajaran Daring, Pendidikan Tinggi, Diskusi Terbimbing,

Media Digital

Keywords:

Online Learning, Higher

Education, Guided Discussion, Digital Media

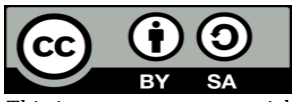

This is an open access article under the CC BY-SA license.

Copyright (C) 2021 by Author. Published by Universitas Pendidikan Ganesha.

\begin{abstract}
A B S T R A K
Penggunaan informasi dan teknologi tidak dapat dihindari dalam dunia pendidikan tinggi. Apalagi didukung dengan penyebaran virus corona yang memaksa para pendidik dan mahasiswa untuk mempersiapkan dan melaksanakan pembelajaran secara daring di Indonesia. Permasalahan yang muncul adalah apakah kegiatan pembelajaran secara daring yang telah berlangsung, telah memenuhi kebutuhan mahasiswa terhadap jadwal, metode, dan media, sehingga pembelajaran menjadi lebih bermakna. Tujuan penelitian ini adalah untuk menganalisis kebutuhan mahasiswa terhadap jadwal, metode, dan media pembelajaran yang dapat meningkatkan literasi baca tulis dan juga literasi digital, sehingga pembelajaran secara daring dapat terlaksana dengan optimal. Jenis penelitian ini adalah kualitatif dengan pendekatan deskriptif. Subjek penelitian berjumlah 55 mahasiswa Pendidikan Guru Sekolah Dasar (PGSD) pada mata kuliah Pembelajaran Matematika di SD. Prosedur pengumpulan data yang digunakan adalah observasi, agnket, wawancara dan dokumentasi. Dari hasil penelitian yang dilakukan didapatkan bahwa, platform yang digunakan dalam pembelajaran online adalah 98,2\% menggunakan LMS dan 96,4\% menggunakan Whatsapp. Kebutuhan mahasiswa terhadap waktu kegiatan daring adalah sebesar 81,8\% mahasiswa memilih perkuliahan dilaksanakan dengan terjadwal, 81,8\% memilih metode pembelajaran diskusi terbimbing, 80\% mahasiswa memilih media pembelajarannya adalah video pembelajaran yang dilengkapi dengan buku referensi dan 98,2\% membutuhkan umpan balik dari dosen yang mengajar. Dengan difasilitasinya kebutuhan mahasiswa terhadap perkuliahan daring, maka kegiatan perkuliahan akan menjadi lebih bermakna untuk meningkatkan literasi baca tulis dan juga literasi digital menjadi lebih baik.
\end{abstract}

\section{A B S T RACT}

The use of information and technology is unavoidable in higher education. Moreover, it is supported by the spread of the coronavirus, which forces educators and students to prepare and carry out online learning in Indonesia. The problem that arises is whether the online learning activities that have taken place have met the student's needs for schedules, methods, and media so that learning becomes meaningful. The purpose of this study was to analyze student needs for schedules, methods, and learning media that can improve literacy and digital literacy so that online learning can be carried out optimally. This type of research is qualitative with a descriptive approach. The research subjects were 55 students of Elementary School Teacher Education (PGSD) in the Mathematics Learning course in SD. The data collection procedures used were observation, questionnaires, interviews and documentation. From the research results, it was found that the platforms used in online learning were 98.2\% using LMS and 96.4\% using Whatsapp. Student needs for online activity time are $81.8 \%$ of students choosing scheduled lectures, $81.8 \%$ choosing guided discussion learning methods, $80 \%$ of students choosing learning media are learning videos equipped with reference books and $98.2 \%$ needing feedback from the teaching lecturer. By facilitating student needs for online lectures, lecture activities will be more meaningful to improve literacy and digital literacy.

\section{PENDAHULUAN}

Adanya pandemi virus covid-19 yang melanda Negara Indonesia telah memberikan dampak pada seluruh tatanan kehidupan masyarakat termasuk pada bidang pendidikan. Selama pandemi Covid-19, hak istimewa yang dimiliki oleh guru untuk bertemu dengan siswa dan mencurahkan waktu untuk memberikan penjelasan terperinci, memantau kemajuan, dan memberi umpan balik kepada siswa berada di bawah tekanan besar (Schneider \& Council, 2021; Surma \& Kirschner, 2020). Kegiatan pembelajaran yang umumnya dilaksanakan secara tatap muka langsung kini diinovasikan menjadi kegiatan tatap muka virtual dengan memanfaatkan kemajuan teknologi (Fitriyani et al., 2020; Rigianti, 2020). Kegiatan pembelajaran dengan menggunakan tatap muka virtual ini umumnya disebut dengan pembelajaran daring (Putra, 2020). Dengan pemanfaatan teknologi pembelajaran daring yang berkembang pesat saat 
ini, kesulitan dalam melakukan pembelajaran jarak jauh bisa teratasi (Kusumaningrum \& Wijayanto, 2020; Zhafira et al., 2020). Melalui pembelajaran daring mahasiswa bisa berdikusi secara langsung baik dengan teman sejawat, maupun dengan pendidik mereka (Handayani \& Irawan, 2020). Teknologi sudah menjembatani untuk melakukan hal tersebut secara virtual (Astini, 2020; Salsabila et al., 2020). Bahkan terlihat lebih mudah tanpa harus berpindah posisi. Kegiatan pembelajaran secara daring telah memberikan banyak manfaat pada tatanan pelaksanaan pendidikan. Salah satu manfaat dari pelaksanaan pembelajaran daring yakni mampu memaksimalkan pengembangan kemampuan non akademik siswa maupun mahasiswa, selain itu pembelajaran secara daring juga mampu meningkatkan kemampuan penggunaan teknologi guru maupun siswa secara signifikan (Fitra et al., 2020; Fitriani, 2021). Dalam bidang kesehatan pelaksanaan pembelajaran daring mampu menekan penyebaran virus covid-19 pada satuan pendidikan, hal ini dikarenakan proses pembelajaran daring dilaksanakan secara virtual dimana guru dan siswa belajar pada waktu yang bersamaan namun pada tempat yang berbeda (Ahmad, 2020; Pertiwi \& Sutama, 2020; Santika, 2020).

Hanya saja, tidak setiap lingkungan pembelajaran daring dapat menghadirkan efek positif yang serupa (Meylani et al., 2015). Pembelajaran tatap muka masih disukai oleh semua orang, hal ini dikarenakan kegiatan pembelajaran tatap muka dapat terpantau secara nyata dan setiap miskonsepsi oleh peserta didik dapat dideteksi dengan cepat, sehingga penyampaian umpan balik konsep khususnya materi matematika pun menjadi lebih tepat dan cepat (Kebritchi et al., 2017; Vallade \& Kaufmann, 2018). Namun pada akhirnya kegiatan pembelajaran tetap dilaksanakan secara online. Pada saat pembelajaran secara daring rencana pembelajaran yang dibuat sebelumnya sudah tidak sesuai lagi dengan keadaan. Strategi, metode, dan media pembelajaran yang telah direncanakan untuk pembelajaran tatap muka, jelas tidak akan dapat diterapkan pada pembelajaran virtual secara keseluruhan. Akibatnya, pembelajaran online hanya merupakan perubahan yang dipaksakan dari pembelajaran tatap muka ke pembelajaran virtual, untuk memenuhi tujuan telaksananya pembelajaran (Dumford \& Miller, 2018). Perubahan pendekatan pembelajaran yang terkesan mendadak memaksa pendidik dan peserta didik untuk cepat beradaptasi dengan keajaiban teknologi (Dumford \& Miller, 2018). Pendidikan online menghadapi berbagai tantangan dalam kepuasan siswa termasuk masalah seperti kualitas pengajaran, silabus yang jelas/tertulis dengan baik, pertemuan fakultas dengan kebutuhan siswa, pendidikan yang harus setara dengan nilai uang kuliah yang dibayarkan, dan persyaratan program yang jelas (Kahar et al., 2021; Napitupulu, 2020). Kemajuan teknologi membuat pelaksanaan pembelajaran menjadi semakin rumit bagi pengguna pemula untuk menjangkau dan berpartisipasi dalam kelas online. Saat ini, kegiatan pembelajaran online tidak terbatas pada modul dan forum diskusi. Pendidikan jarak jauh telah mencakup berbagai program seperti teknologi multimedia, streaming video, grafik, komunikasi suara, applet, dan lainnya teknologi canggih yang mungkin harus dipasang dan dikonfigurasi untuk memenuhi tujuan pembelajaran (Yaumi \& Damopolii, 2019). Karena persyaratan teknis tambahan ini, pendidik, peserta didik, dan seluruh support system di perguruan tinggi diakrabkan ke platform dan teknologi yang terlibat untuk memastikan keberhasilan siswa di kelas virtual.

Mata kuliah pembelajaran matematika di SD memiliki bobot 3 satuan kredit semester (sks) yang secara keseluruhan materi perkuliahannya adalah teori. Kecenderungan pelaksanaan mata kuliah yang hanya teori saja pada saat tatap muka adalah pasif. Ada kelompok yang menjelaskan dan ada kelompok yang hanya mendengarkan, kegiatan diskusi pun tidak berjalan begitu antusias. Sehingga, peralihan pembelajaran tatap muka ke pembelajaran daring menyulut ke kekhawatiran dosen, nantinya pembelajaran secara daring melalui platform-platform pembelajaran online menjadi semakin tidak bermakna. Hal ini, dikarenakan pembelajaran secara daring membutuhkan kesadaran secara penuh kepada siswa untuk meningkatkan kemampuan literasi membaca dan juga literasi digital. Pelaksanaan literasi digital membutuhkan waktu untuk beradaptasi, baik bagi dosen yang merancang kegiatan pembelajaran daring dan juga mahasiswa sebagai penggunanya (Tahmidaten \& Krismanto, 2020).

Beberapa penelitian yang telah dilaksanakan sebelumnya menyebutkan bahwa secara keseluruhan proses pembelajaran daring berjalan sudah cukup baik, hanya saja masih terdapat banyak kendala yang dihadapi oleh mahasiswa seperti kurangnya kemampuan siswa dalam memahami materi yang disajikan oleh guru, sehingga untuk mengatasi permasalah tersebut perlu diupayakan untuk memberikana variasi pada metode atau aplikasi pembelajaran guna mengurangi kejenuhan dalam pembelajaran, selain itu sistem evaluasi yang digunakan harus diperhatikan agar tidak mudah untuk terjadi kecurangan karena mahasiswa dapat melihat kunci jawaban yang sudah dibuat oleh dosen (Karlina et al., 2021). Hasil penelitian lainnya juga menyatakan bahwa berdasarkan hasil evaluasi pembelajaran daring ditemukan bahwa secara umum pelaksanaan pembelajaran daring telah terlaksana dengan baik, hanya saja terdapat sedikit permasalahan pada bagian teknis, dimana persoalan jaringan dan biaya paket data menjadi perhatian para mahasiswa (Yudiawan, 2020). Penelitian selanjutnya menyebutkan bahwa pada saat pembelajaran daring mahasiswa lebih banyak membutuhkan buku referensi, internet dan 
kuota, buku panduan praktikum, kamus nama ilmiah, bahan ajar, dan e-learning (Yuhanna, 2021). Berdasarkan beberapa hasil penelitian terdahulu dapat dikatakan bahwa pelaksanaan pembelajaran daring masih belum berjalan dengan maksimal, hal ini dikarenakan pada proses evaluasi ditemukan banyak kendala yang dialami oleh mahasiswa, selain itu terdapat banyak kebutuhan mahasiswa yang belum terpenuhi. Hanya saja pada penelitian sebelumnya belum terdapat kajian mengenai evaluasi pembelajaran daring mahasiswa pada mata kuliah pembelajaran matematika di SD. Sehingga penelitian ini difokuskan pada hal tersebut dengan tujuan untuk menganalisis kebutuhan mahasiswa terhadap jadwal, metode, dan media pembelajaran yang dapat meningkatkan literasi baca tulis dan juga literasi digital, sehingga pembelajaran secara daring dapat terlaksana dengan optimal.

\section{METODE}

Penelitian ini menggunakan jenis penelitian deskriptif kualitatif. Penelitian kualitatif adalah penelitian yang bermaksud untuk memahami fenomena tentang apa yang dialami oleh subjek penelitian misalnya perilaku, persepsi, motivasi, tindakan, dan lain-lain, secara holistik, dan dengan cara deskripsi dalam bentuk kata-kata dan bahasa, pada suatu konteks khusus yang alamiah dengan memanfaatkan berbagai metode ilmiah. Subjek yang terlibat dalam penelitian ini yakni mahasiswa semester 2 sebanyak 55 orang yang mengambil mata kuliah pembelajaran matematika SD, di jurusan Pendidikan Guru Sekolah Dasar, Fakultas Ilmu Pendidikan Universitas Negeri Padang. Subyek penelitian ini, sebelumnya telah melakukan pembelajaran online selama 8 pertemuan. Sehingga mereka dapat menilai kebutuhan mereka untuk pembelajaran online pada pertemuan-pertemuan selanjutnya. Metode pengumpulan data yang digunakan yakni metode wawancara secara langsung kepada beberapa mahasiswa yang dipilih secara acak, selanjutnya melakukan observasi dan membagikan quesioner (angket) kepada mahasiswa, serta mendokumentasikan kegiatan untuk memperkuat data penelitian. Penyebaran angket dilakukan kepada dua kelas mata pelajaran matematika untuk mata pelajaran sekolah dasar. Kuesioner yang diberikan bertujuan untuk mengevaluasi pembelajaran online yang sedang berlangsung serta mengidentifikasi kebutuhan mahasiswa akan pembelajaran online untuk pertemuan berikutnya dalam mata kuliah pembelajaran matematika di sekolah dasar. Adapun indikator evaluasi dan kebutuhan masiswa terhadap pembelajaran daring disajikan pada Tabel 1.

Tabel 1. Indikator Evaluasi dan Kebutuhan Masiswa terhadap Pembelajaran daring

\begin{tabular}{|c|c|c|}
\hline Variabel & Sub Varibel & Indikator \\
\hline \multirow[t]{5}{*}{$\begin{array}{c}\text { Evaluasi } \\
\text { pembelajaran }\end{array}$} & $\begin{array}{lcr}\text { Mahasiswa } & \text { yang mengisi } & \text { adalah } \\
\text { mahasiswa } & \text { semester } 2 & \text { yang } \\
\text { mengambil } & \text { mata } & \text { kuliah }\end{array}$ & $\begin{array}{ll}\text { - } & \text { Identitas, NIM dan Nama } \\
\text { - Jumlah SKS pada semester tersebut }\end{array}$ \\
\hline & $\begin{array}{l}\text { Pembelajaran Matematika di SD } \\
\text { Mahasiswa memiliki perangkat dan } \\
\text { jaringan dalam mengikuti } \\
\text { perkuliahan secara daring. }\end{array}$ & $\begin{array}{l}\text { - Perangkat yang digunakan untuk } \\
\text { pembelajaran daring. } \\
\text { - } \quad \text { Lokasi selama mengikuti nerkuliahan daring }\end{array}$ \\
\hline & $\begin{array}{l}\text { Kesungguhan mahasiswa dalam } \\
\text { melaksanakan kuliah secara daring }\end{array}$ & $\begin{array}{l}\text { Kesungguhan dalam pelaksanaan daring } \\
\text { yang telah terlaksana } \\
\text { Pemahaman terhadap materi selama } \\
\text { pembelajaran daring }\end{array}$ \\
\hline & $\begin{array}{l}\text { Biaya yang dihabiskan untuk } \\
\text { pelaksanaan daring dengan } \\
\text { menggunakan platform-platform } \\
\text { online pembelajaran. }\end{array}$ & $\begin{array}{l}\text { - Harga paket data yang dihabiskan untuk } \\
\text { pembelajaran daring } \\
\text { - Platform online yang digunakan selama } \\
\text { pembelajaran daring berlangsung } \\
\text { - Waktu pelaksanaan daring yang telah } \\
\text { berlangsung }\end{array}$ \\
\hline & $\begin{array}{l}\text { Metode dan media yang digunakan } \\
\text { dalam perkuliahan daring, dan juga } \\
\text { pemberian umpan balik oleh dosen } \\
\text { terhadap perkuliahan yang telah } \\
\text { dilaksanakan. }\end{array}$ & $\begin{array}{l}\text { - Media yang digunakan dosen selama } \\
\text { pembelajaran daring berlangsung } \\
\text { - Metode pembelajaran daring yang umumnya } \\
\text { dilaksanakan } \\
\text { - Pemberian umpan balik oleh dosen selama } \\
\text { pembelajaran daring }\end{array}$ \\
\hline $\begin{array}{l}\text { Kebutuhan } \\
\text { Mahasiswa }\end{array}$ & $\begin{array}{l}\text { kebutuhan mahasiswa dalam } \\
\text { perkuliahan yang dilaksanakan }\end{array}$ & $\begin{array}{l}\text { - Mahasiswa menentukan media yang mereka } \\
\text { butuhkan untuk meningkatkan pemahaman }\end{array}$ \\
\hline
\end{tabular}




\begin{tabular}{llll}
\hline Variabel & \multicolumn{1}{c}{ Sub Varibel } & \multicolumn{1}{c}{ Indikator } \\
\hline & secara daring, meliputi media, & & pembelajaran \\
& metode, jadwal, dan pemberian & $\bullet$ & Mahasiswa memilih metode pembelajaran \\
& umpan balik secara transparan & & untuk pembelajaran daring \\
terhadap hasil kerja, partisipasi, & $\bullet$ & Mahasiswa menentukan waktu perkuliahan \\
& dan tugas-tugas yang diberikan & & daring yang efektif menurut mereka \\
melalui platform pembelajaran & $\bullet$ & Mahasiwa memilih ketersediaan feedback \\
& online & dalam perkuliahan. \\
\hline
\end{tabular}

Data hasil penelitian kemudian dianalisis dengan menggunakan teknik analisis data Miles dan Huberman. Pada analisis data dilakukan proses pengumpulan data, reduksi data, penyajian data, serta penarikan kesimpulan/verifikasi. Dengan memenuhi kebutuhan mahasiswa pada pembelajaran daring, diharapkan pembelajaran bisa menjadi lebih bermakna bagi mereka dan pembelajaran secara daring pun bisa terlaksana secara maksimal untuk mendukung meningkatkan kecakapan literasi baca tulis dan literasi digital. Hasil analisis kebutuhan kemudian dikonfersikan kedalam tabel kategori kebutuhan mahasiswa terhadap pembelajaran daring yang disajikan pada Tabel 2.

Tabel 2. Kategori Kebutuhan Mahasiswa terhadap Pembelajaran Daring

\begin{tabular}{cc}
\hline Persentase Kebutuhan & Kategori \\
$\mathbf{8 0 \%}-\mathbf{1 0 0} \%$ & Tinggi \\
$\mathbf{7 0 \%}-\mathbf{7 9 \%}$ & Cukup \\
$\mathbf{6 0 \%}-\mathbf{6 9 \%}$ & Kurang \\
$\mathbf{> 5 9 \%}$ & Tidak Butuh \\
\hline
\end{tabular}

\section{HASIL DAN PEMBAHASAN}

\section{Hasil}

Hasil observasi dan wawancara yang telah dilaksanakan bersama subjek penelitian menunjukkan bahwa Universitas Negeri Padang (UNP) telah mengembangkan platform e-learning sendiri melalui learning management system (LMS) yaitu MOODLE Dari hasil survei diketahui bahwa 98,2\% perkuliahan online menggunakan portal e-learning UNP dan dilengkapi dengan Aplikasi WhatsApp sebagai media komunikasi. Selain itu, aplikasi zoom juga digunakan oleh sebagian besar perkuliahan online, meskipun sudah tersedia webmeeting berupa big blue button pada LMS universitas. Hasil analisis angket serta dokumen yang telah dilakukan peneliti, menunujukkan bahwa responden yang menempuh pendidikan di semester 2, sksnya pada semester ini cukup banyak yaitu antara 20 sd 21 sks. Karena itu, 81,8\% responden lebih memilih kegiatan pembelajaran online dilakukan secara terjadwal. Hal ini berdasarkan hasil evaluasi pembelajaran online yang telah berlangsung, menunjukkan lebih dari separuh mata kuliah tidak mengikuti jadwal yang telah ditentukan. Ada beberapa metode yang digunakan dosen dalam pembelajaran online, antara lain presentasi online, tugas mandiri, dan diskusi. Namun hasil penelitian menunjukkan bahwa siswa lebih memilih metode diskusi terbimbing untuk kelas online mereka, yaitu sebanyak $81,8 \%$. Untuk melengkapi metode ini, siswa memilih video pembelajaran, buku referensi, dan power point sebagai media pembelajaran online. Sebagai pelengkap metode dan media pembelajaran tersebut, 98,2\% siswa menginginkan umpan balik untuk setiap aktivitas pembelajaran online yang mereka lakukan. Secara lebih rinci hasil persentase kebutuhan pembelajaran daring mahasiswa disajikan pada Tabel 3.

Tabel 3. Persentase Kebutuhan Pembelajaran Daring Terhadap Platform, Jadwal, Metode, Media, dan Umpan Balik

\begin{tabular}{llcc}
\hline \multicolumn{1}{c}{ Variabel } & \multicolumn{1}{c}{ Pilihan } & Persentase & Kategori \\
\hline Platform yang digunakan selama daring & Portal E-learning UNP & $98,2 \%$ & Tinggi \\
& Zoom & $92,7 \%$ & Tinggi \\
& Whatsapp & $96,4 \%$ & Tinggi \\
Jadwal pelaksanaan pembelajaran daring & Terjadwal dan sesuai SKS & $81,8 \%$ & Tinggi \\
Metode pembelajaran daring & Diskusi terbimbing & $81,8 \%$ & Tinggi \\
Media pembelajaran daring & PPT+Video + Buku referensi & $80 \%$ & Tinggi \\
Umpan Balik & Perlu & $98,2 \%$ & Tinggi \\
\hline
\end{tabular}




\section{Pembahasan}

Hasil analisis data penelitian menunjukkan bahwa pelaksanaan pembelajaran daring di Universitas Negeri Padang (UNP) telah berlangsung dengan cukup baik, hal ini dikarenakan tenaga pengajar telah mampu memenuhi kebutuhan mahasiswa. Hal ini sangat sesuai dengan tuntutan tugas utama seorang dosen yakni mengajar dan mengkondisikan mahasiswa untuk belajar secara aktif, sehingga itupotensi mereka (kognitif, afektif, dan konatif) dapat berkembang secara optimal. Kegiatan belajar mengajar di pendidikan tinggi adalah proses bersama, dengan tanggung jawab pada siswa, dan guru berkontribusi pada keberhasilan mereka (Bidabadi et al., 2016). Dalam proses bersama ini, perguruan tinggi harus melibatkan mahasiswa dalam mempertanyakan ide-ide mereka sebelum masalah utama dibahas dan pendapat mereka tentang bagaimana dunia nyata bekerja, sehingga mereka dapat mencapai tingkat pemahaman yang lebih tinggi (Cheung et al., 2021; Gewin, 2020; Widyasari et al., 2019). Salah satu kebutuhan mahasiswa selama proses pembelajaran daring yakni kebutuhan akan penggunaan strategi pembelajaran yang efektif serta efisien guna mempermudah mahasiswa dalam memahami materi ajar. Salah satu strategi yang dapat digunakan yakni strategi diskusi terbimbing. Strategi diskusi terbimbing adalah salah satu strategi yang dapat menghubungkan pembelajaran dengan situasi kelas, di mana masing-masing murid adalah individu yang unik, yang diberkahi dengan kemampuan intelektual untuk berpikir dan bertindak sebagai individu dan sebagai grup anggota (Cheung et al., 2021). Siswa memiliki kemampuan untuk menyesuaikan diri secara bermakna satu sama lain dan dengan dunia mereka. Kebersamaan mereka untuk memecahkan masalah sosial sebagai sebuah kelompok dapat memberikan mereka stimulasi untuk berkontribusi aktif dalam pembelajaran. Peran guru dalam kegiatan diskusi terbimbing tentunya juga berperan besar dalam keberhasilan mahasiswa dalam mencapai tujuan pembelajaran. Dengan adanya diskusi terbimbing, guru dapat mempertanyakan prasangka mahasiswa, dan memotivasi mereka untuk belajar dengan menempatkan mereka dalam situasi sebagai penulis jawaban, dan berfungsi sebagai agen tanggung jawab terhadap kontribusi mereka di dalam mencapai tujuan pembelajaran di dalam sebuah kegiatan diskusi (Bidabadi et al., 2016; Sangsawang, 2020). Meskipun begitu, dalam kegiatan diskusi yang dilaksanakan secara daring, tidak bisa terlepas begitu saja tanpa ada umpan balik dari guru terhadap pendapat-pendapat yang telah mereka sampaikan. Guru bertugas untuk membangun situasi dan kondisi dimana siswa dapat membangun kepercayaan diri, dan mengaplikasikan pengetahuan mereka dalam memecahkan masalah yang telah dirancang oleh guru, sehingga hambatan dalam mencapai tujuan pembelajaran dapat diatasi (Cheung et al., 2021; Sangsawang, 2020).

Partisipasi siswa dalam diskusi online dapat ditingkatkan dengan menggabungkan diskusi audio atau video dengan diskusi teks online (Ice et al., 2019). Komponen audio atau video meningkatkan komunikasi dan hubungan dengan teman sebaya, mendorong siswa untuk berpartisipasi dalam diskusi, dan mendukung siswa untuk menguraikan tanggapan mereka, karena memfasilitasi komunikasi yang memakan waktu lebih sedikit dibandingkan dengan diskusi teks. Guru dituntu untuk memiliki sikap positif terhadap teknologi dan pemahaman yang baik tentang cara menggunakan teknologi, sehingga pembelajaran online menjadi pengalaman belajar yang positif bagi siswa (Dalton, 2018; Surma \& Kirschner, 2020). Selain itu,guru harus dapat menjawab pertanyaan dasar tentang cara menavigasi LMS dan menggunakan teknologi yang diperlukan (Ana, 2020; Dalton, 2018). Desain kursus yang baik yang mencakup tutorial tentang LMS dan teknologi lain yang diperlukan akan sangat membantu dalam masalah teknologi. Konten yang dapat dikembangkan berdasarkan strategi, yakni konten yang mampu mengintegrasikan multimedia untuk meningkatkan pengalaman belajar menggunakan prinsip-prinsip teori konstruktivis (Sangsawang, 2020). Beberapa contoh dari multimedia termasuk game, video, dan simulasi. Penting untuk dicatat bahwa hanya memasukkan multimedia ke dalam desain kursus online tidak selalu sesuai menjawab tujuan pembelajaran secara langsung. Guru perlu bertanya pada diri sendiri teknologi apa yang akan menambah aktivitas belajar. Multimedia, jika digunakan dengan cara yang salah, mungkin berimplikasi proses belajar.

Sebagai guru yang mengembangkan pembelajaran online paling luar biasa, tidak cukup dengan metode dan media yang mumpuni, tetapi juga menyediakan umpan balik yang berguna bagi siswa sehingga pembelajaran kegiatan benar-benar dilaksanakan (Dalton, 2018; Gewin, 2020). Umpan balik penting bagi otak. Ketika seorang siswa diberikan umpan balik pada respon yang salah, sejumlah: proses saraf dan aktivitas otak dipicu; komentar yang diberikan oleh umpan balik akan memperkuat untuk memperbaiki informasi. Selain itu, umpan balik yang positif merupakan indikasi bahwa pembelajaran memang telah terjadi yang mendorong siswa untuk terus mengerjakan lebih banyak materi terlepas dari tingkat kesulitannya (Meylani et al., 2015). Struktur ideal kurikulum ini menantang tetapi tidak membuat siswa frustasi. Saat memberikan umpan balik, manajemen waktu penting bagi guru. Memberikan umpan balik yang tepat waktu kepada setiap siswa dan kelompok sangat penting dalam lingkungan online. LMS akan memiliki fitur bawaan untuk memberikan umpan balik seperti ujian, kuis, atau survei. Jenis penilaian 
ini otomatis dan sederhana (Dalton, 2018). Tugas kompleks yang membutuhkan penulisan akan memakan waktu lebih lama untuk dinilai. Memberikan umpan balik langsung pada makalah yang diunduh atau ke dalam kotak teks LMS adalah metode yang cocok untuk memberikan arahan kepada siswa. Video dapat dibuat untuk memberikan umpan balik kepada siswa untuk semua jenis pekerjaan, tetapi itu adalah ide yang baik ketika menilai kerja kelompok.

Tujuan utama dari umpan balik adalah untuk memungkinkan siswa mengetahui apakah mereka membuat kemajuan yang cukup untuk mencapai pembelajaran tujuan (Cheung et al., 2021; Dalton, 2018; Hew et al., 2020). Sangat penting dalam pembelajaran online untuk memberikan siswa dengan jenis penilaian formatif yang bervariasi dan sering. Jika tidak, siswa mungkin tidak dapat memperbaiki masalah yang dihadapi dalam tugas sebelum penilaian sumatif (Hew et al., 2020). Pemberian umpan balik kepada siswa terjadi dalam berbagai cara termasuk jenis penilaian yang lebih otentik seperti pembelajaran berbasis masalah yang memungkinkan masukan diberikan untuk disposisi, pengetahuan, dan keterampilan yang berkaitan dengan pemikiran kritis, pemecahan masalah, dan kerja kelompok (Cheung et al., 2021; Dalton, 2018). Jenis lain dari penilaian otentik yang efektif dalam pembelajaran online adalah pembelajaran kolaboratif yang memungkinkan kelompok siswa untuk bekerja sama untuk hasil belajar bersama (Cerro Martínez et al., 2020; Gewin, 2020).

Hasil yang diperoleh pada penelitian ini sejalan dengan hasil penelitian terdahulu yang juga menyebutkan bahwa secara keseluruhan proses pembelajaran daring berjalan sudah cukup baik, hanya saja masih terdapat banyak kendala yang dihadapi oleh mahasiswa seperti kurangnya kemampuan siswa dalam memahami materi yang disajikan oleh guru, sehingga untuk mengatasi permasalah tersebut perlu diupayakan untuk memberikana variasi pada metode atau aplikasi pembelajaran guna mengurangi kejenuhan dalam pembelajaran, selain itu sistem evaluasi yang digunakan harus diperhatikan agar tidak mudah untuk terjadi kecurangan karena mahasiswa dapat melihat kunci jawaban yang sudah dibuat oleh dosen (Karlina et al., 2021). Hasil penelitian lainnya juga menyatakan bahwa berdasarkan hasil evaluasi pembelajaran daring ditemukan bahwa secara umum pelaksanaan pembelajaran daring telah terlaksana dengan baik, hanya saja terdapat sedikit permasalahan pada bagian teknis, dimana persoalan jaringan dan biaya paket data menjadi perhatian para mahasiswa (Yudiawan, 2020). Penelitian selanjutnya menyebutkan bahwa pada saat pembelajaran daring mahasiswa lebih banyak membutuhkan buku referensi, internet dan kuota, buku panduan praktikum, kamus nama ilmiah, bahan ajar, dan e-learning (Yuhanna, 2021). Sehingga berdasarkan hal tersebut dapat dikatakan bahwa pembelajaran daring telah terlaksana dengan baik, hanya saja masih membutuhkan perhatian dosen untuk memaksimalkan kebutuhan mahasiswa.

\section{SIMPULAN}

Pelaksanaan pembelajaran daring di Universitas Negeri Padang (UNP) telah berlangsung dengan cukup baik, hal ini dikarenakan tenaga pengajar telah mampu memenuhi kebutuhan mahasiswa. Hal ini sangat sesuai dengan tuntutan tugas utama seorang dosen yakni mengajar dan mengkondisikan mahasiswa untuk belajar secara aktif, sehingga itupotensi mereka (kognitif, afektif, dan konatif) dapat berkembang secara optimal.

\section{DAFTAR PUSTAKA}

Ahmad, I. F. (2020). Asesmen Alternatif Dalam Pembelajaran Jarak Jauh Pada Masa Darurat Penyebaran Coronavirus Disease (Covid-19) Di Indonesia. Pedagogik: Jurnal Pendidikan, 7(1), 195-222. https://doi.org/10.33650/pjp.v7i1.1136.

Ana, A. (2020). Trends in expert system development: A practicum content analysis in vocational education for over grow pandemic learning problems. Indonesian Journal of Science and Technology, 5(2), 246-260. https://doi.org/10.17509/ijost.v5i2.24616.

Astini, N. K. suni. (2020). Tantangan Dan Peluang Pemanfaatan Teknologi Informasi Dalam Pembelajaran Online Masa Covid-19. Cetta: Jurnal Ilmu Pendidikan, 3(2), 241-255. https://doi.org/10.37329/cetta.v3i2.452.

Bidabadi, N. S., Isfahani, A. N., Rouhollahi, A., \& Khalili, R. (2016). Effective Teaching Methods in Higher Education: Requirements and Barriers. Journal of Advances in Medical Education \& Professionalism, 4(4), 170-178. https: //pubmed.ncbi.nlm.nih.gov/27795967/.

Cerro Martínez, J. P., Guitert Catasús, M., \& Romeu Fontanillas, T. (2020). Impact of using learning analytics in asynchronous online discussions in higher education. International Journal of Educational Technology in Higher Education, 17(1). https://doi.org/10.1186/s41239-020-00217-y.

Cheung, S. K. S., Kwok, L. F., Phusavat, K., \& Yang, H. H. (2021). Shaping the future learning environments 
with smart elements: challenges and opportunities. International Journal of Educational Technology in Higher Education, 18(1), 1-9. https://doi.org/10.1186/s41239-021-00254-1.

Dalton, M. H. (2018). Online Programs in Higher Education: Strategies for Developing Quality Courses. FOCUS on Colleges, Universities \& $\quad$ Schools, $\quad 12(1)$. http://www.nationalforum.com/Journals/FOCUS/FOCUS.htm.

Dumford, A. D., \& Miller, A. L. (2018). Online learning in higher education: exploring advantages and disadvantages for engagement. Journal of Computing in Higher Education, 30(3), 452-465. https://doi.org/10.1007/s12528-018-9179-z.

Fitra, A., Sianturi, F., \& Pangabean, A. E. (2020). Pelatihan Dan Pendampingan Pemanfaatan Google Classroom Sebagai Media Pembelajaran Secara Daring Bagi Siswa SMP Authors. Jurnal Penelitian Dan Pengabdian Kepada Masyarakat, 1(3). https://doi.org/10.25008/altifani.v1i3.154.

Fitriani, rita. (2021). Kesiapan Mahasiswa Calon Guru Mengikuti Pembelajaran Fisika Secara Daring Saat Pandemi Covid-19. Indonesian Journal of Intellectual Publication, 1(2), 90-96. https://doi.org/10.51577/ijipublication.v1i2.63.

Fitriyani, Y., Fauzi, I., \& Sari, M. Z. (2020). Motivasi Belajar Mahasiswa Pada Pembelajaran Daring Selama Pandemik Covid-19. Jurnal Hasil Penelitian Dan Kajian Kepustakaan Di Bidang Pendidikan, Pengajaran Dan Pembelajaran, 6(2), 165. https://doi.org/10.33394/jk.v6i2.2654.

Gewin, V. (2020). Five tips for moving teaching online as COVID-19 takes hold. Nature, 580(7802), 295296. https://doi.org/10.1038/d41586-020-00896-7.

Handayani, S. D., \& Irawan, A. (2020). Pembelajaran matematika di masa pandemic covid-19 berdasarkan pendekatan matematika realistik. Jurnal Math Educator Nusantara: Wahana Publikasi Karya Tulis Ilmiah Di Bidang Pendidikan Matematika, 6(2), 179-189. https://doi.org/10.29407/jmen.v6i2.14813.

Hew, K. F., Jia, C., Gonda, D. E., \& Bai, S. (2020). Transitioning to the "new normal" of learning in unpredictable times: pedagogical practices and learning performance in fully online flipped classrooms. International Journal of Educational Technology in Higher Education, 17(1). https://doi.org/10.1186/s41239-020-00234-X.

Ice, P., Curtis, R., Phillips, P., \& Wells, J. (2019). Using Asynchronous Audio Feedback To Enhance Teaching Presence And Students' Sense of Community. Online Learning, 11(2). https://doi.org/10.24059/olj.v11i2.1724.

Kahar, M. I., Cika, H., Afni, nur, \& Wahyuningsih, N. E. (2021). Pendidikan Era Revolusi Industri 4.0 Menuju Era Society 5.0 Di Masa Pandemi Covid 19. Moderasi: Jurnal Studi Ilmu Pengetahuan Sosial, 2(1), 58-78. https://doi.org/10.24239/moderasi.Vol2.Iss1.40.

Karlina, D. A., Nugraha, D., D, A. L. I., \& Halimatu, P. (2021). Analisis pembelajaran daring pada mahasiswa PGSD di masa pandemik. Jurnal Kajian Pendidikan Umum, 19(1), 7-12. https: //ejournal.upi.edu/index.php/SosioReligi/article/view/39344/16420.

Kebritchi, M., Lipschuetz, A., \& Santiague, L. (2017). Issues and Challenges for Teaching Successful Online Courses in Higher Education. Journal of Educational Technology Systems, 46(1), 4-29. https://doi.org/10.1177/0047239516661713.

Kusumaningrum, B., \& Wijayanto, Z. (2020). Apakah Pembelajaran Matematika Secara Daring Efektif? (Studi Kasus pada Pembelajaran Selama Masa Pandemi Covid-19). Jurnal Matematika Kreatif Dan Inovatif, 11(2). https://doi.org/10.15294/kreano.v11i2.25029.

Meylani, R., Bitter, G., \& Legacy, J. (2015). Desirable Characteristics of an Ideal Online Learning Environment. Journal of Educational and Social Research, 5(1), 203-216. https://doi.org/10.5901/jesr.2015.v5n1p203.

Napitupulu, R. M. (2020). Dampak pandemi Covid-19 terhadap kepuasan pembelajaran jarak jauh. Jurnal Inovasi Teknologi Pendidikan, 7(1), 23-33. https://doi.org/10.21831/jitp.v7i1.32771.

Pertiwi, R., \& Sutama, S. (2020). Membudayakan Kelas Digital Untuk Membimbing Siswa dalam Pembelajaran di Tengah Pandemi Covid-19. JKTP: Jurnal Kajian Teknologi Pendidikan, 3(4), 350365. https://doi.org/10.17977/um038v3i42020p350.

Putra, N. P. (2020). Solusi Pembelajaran Jarak Jauh Menggunakan Aplikasi Zoom Dan Whatsapp Group Di Era New Normal Pada Warga Belajar Paket C Di Pusat Kegiatan Belajar Masyarakat (PKBM) Bina Insani. Jipsindo, 7(2), 162-176. https://doi.org/10.21831/jipsindo.v7i2.34939.

Rigianti, H. A. (2020). Kendala Pembelajaran Daring Guru Sekolah Dasar Di Banjarnegara. Elementary School: Jurnal Pendidikan Dan Pembelajaran Ke-SD-An, 7(2). https://doi.org/10.31316/esjurnal.v7i2.768.

Salsabila, U. H., Sari, L. I., Lathif, K. H., Lestari, A. P., \& Ayuning, A. (2020). Peran Teknologi Dalam Pembelajaran Di Masa Pandemi Covid-19. Al-Mutharahah: Jurnal Penelitian Dan Kajian Sosial Keagamaan, 17(2), 188-198. https://doi.org/10.46781/al-mutharahah.v17i2.138. 
Sangsawang, T. (2020). An instructional design for online learning in vocational education according to a self-regulated learning framework for problem solving during the covid-19 crisis. Indonesian Journal of Science and Technology, 5(2), 283-198. https://doi.org/10.17509/ijost.v5i2.24702.

Santika, I. W. E. (2020). Pendidikan Karakter pada Pembelajaran Daring. Indonesian Values and Character Education Journal, 3(1). https://doi.org/10.23887/ivcej.v3i1.27830.

Schneider, S. L., \& Council, M. L. (2021). Distance learning in the era of COVID-19. Archives of Dermatological Research, 313(5), 389-390. https://doi.org/10.1007/s00403-020-02088-9.

Surma, T., \& Kirschner, P. A. (2020). Technology enhanced distance learning should not forget how learning happens. Computers in Human Behavior, 110(1), 106390. https://doi.org/10.1016/j.chb.2020.106390.

Tahmidaten, L., \& Krismanto, W. (2020). Permasalahan Budaya Membaca di Indonesia (Studi Pustaka Tentang Problematika \& Solusinya). Scholaria: Jurnal Pendidikan Dan Kebudayaan, 10(1), 22-33. https://doi.org/10.24246/j.js.2020.v10.i1.p22-33.

Vallade, J. I., \& Kaufmann, R. (2018). Investigating instructor misbehaviors in the online classroom. Communication Education, 67(3), 363-381. https://doi.org/10.1080/03634523.2018.1467027.

Widyasari, Y. D. L., Nugroho, L. E., \& Permanasari, A. E. (2019). Persuasive technology for enhanced learning behavior in higher education. International Journal of Educational Technology in Higher Education, 16(1), 15. https://doi.org/10.1186/s41239-019-0142-5.

Yaumi, M., \& Damopolii, M. (2019). Model Integrasi Teknologi Informasi dan Komunikasi dalam Pembelajaran Jarak Jauh. Jurnal Pendidikan Islam Dan Keguruan, 1(2). https://doi.org/10.5281/zenodo.3545637.

Yudiawan, A. (2020). Belajar Bersama Covid 19: Evaluasi Pembelajaran Daring Era Pandemi di Perguruan Tinggi Keagamaan Islam Negeri, Papua Barat. AL-FIKR: Jurnal Pendidikan Islam, 6(1), 10-16. https://doi.org/10.32489/alfikr.v6i1.64.

Yuhanna, W. L. (2021). Analisis Kebutuhan Belajar Mahasiswa pada Perkuliahan Zoologi Vertebrata di Masa Pandemi Covid19. JEMS (Jurnal Edukasi Matematika Dan Sains), 9(1). http://doi.org/10.25273/jems.v9i1.8803.

Zhafira, N. H., Ertika, Y., \& Chairiyaton, C. (2020). Persepsi Mahasiswa Terhadap Perkuliahan Daring Sebagai Sarana Pembelajaran. Jurnal Bisnis Dan Kajian Strategi Manajemen, 4(1). https://doi.org/10.35308/jbkan.v4i1.1981. 